\title{
Studies on Occurrence of Trichinellosis in Pigs and Its Molecular Characterization Using Multiplex PCR in Maharashtra, India
}

\author{
L.N. Kale ${ }^{1}$, R.N. Waghamare ${ }^{2}$, V.M. Vaidya ${ }^{1}$, R.J. Zende ${ }^{1}$, A.M. Paturkar ${ }^{1}$, R.G. \\ Shende $^{1}$, N.B. Aswar ${ }^{1}$ and D.P. Kshirsagar ${ }^{1}$ \\ ${ }^{1}$ Department of Veterinary Public Health, Bombay Veterinary College, Mumbai, India \\ ${ }^{2}$ Department of Veterinary Public Health, College of Veterinary and Animal Sciences, \\ Parbhani, 431402, India
}

*Corresponding author

\begin{abstract}
A B S T R A C T
Keywords

Prevalence, Multiplex PCR, Acid-pepsin digestion, Trichinella

Article Info

Accepted:

26 July 2018

Available Online:

10 August 2018

Trichinellosis is important food-borne parasitic zoonoses caused by consumption of raw or under-cooked meat from a wide variety of wild and domestic mammals. Pork is consumed across the various pockets of India and it is most important source of infection to humans for Trichinellosis. Recent reports on presence of Trichinella spp. in pork sold in Maharashtra, India is concern for consumers. Therefore the study was planned to check occurrence of Trichinella in pork sold in Mumbai by Acid-pepsin digestion assay and multiplex PCR. Acid-pepsin digestion assay could not able to isolate single larvae from 161 samples similar results were also observed by standardized multiplex PCR. Though none of the sample was found to be positive for Trichinella spp. in present study but standardized multiplex PCR assay using standard larvae of $T$. spiralis and $T$. britovi can be useful for differentiation of $T$. britovi and $T$. spiralis larvae in Indian condition. Regular monitoring and surveillance of trichinellosis in pigs and other reservoirs by acid pepsin digestion assay and multiplex PCR is necessary.
\end{abstract}

\section{Introduction}

Trichinellosis, one of the most important food-borne parasitic zoonoses worldwide, is caused by the consumption of raw or undercooked meat from a wide variety of wild and domestic mammals (Dupouy- Camet, 2000). Pork is consumed across the various pockets of India and it is most important source of infection to humans for Trichinellosis. The occurrence of Trichinella in domestic animal populations is particularly due to poor management practices which allow pigs to consume food contaminated with Trichinella infected meat is the main cause of trichinellosis in pigs (Campbell, 1988). Pigs can only become infected with Trichinella by ingesting raw or undercooked meat containing infective larvae. Thus pig is the major source of Trichinellosis in humans.

There are 8 recognized species of Trichinella and are grouped under encapsulated and nonencapsulated clad. The different species of Trichinella are Trichinella spiralis (T-1), Trichinella native (T-2), Trichinella 
britovi(T-3), Trichinella pseudospiralis (T-4), Trichinella murrelli (T-5), Trichinella nelsoni(T-7), Trichinella papuae (T-10) and Trichinella zimbabwensis (T-11) and four genotypes viz. Trichinella T-6, Trichinella T8, Trichinella T-9 and Trichinella T-12 (Gajadhar et al., 2006 and Gottstein et al., 2009). All these species and genotypes have got zoonotic potential. Trichinella spiralis is the most important species because it is most commonly associated with disease in humans and very much adapted to domestic swine with a direct life cycle (Gottstein et al., 2009).

The pigs are important for food security in India. The unhygienic slaughtering of food animals and presence of scavenging pigs is common in India and could be an important risk for occurrence of trichinellosis in humans in India (Singh et al., 2013). In India, Trichinella has been conclusively isolated from cat, rodents and domestic pigs, (Kalapesi and Rao, 1954; Niphadkar, 1973; and Pethe, 1992; Chetan Kumar, 2011; Jundale, 2015; and Panchal, 2016). In different works various species of Trichinella have been isolated from India, mainly T.spiralis, T.britovi and T.pseudospiralis has been reported in country.

Within most parasite genera, distinct morphological and/or biological characters exist amongthe species that permit differentiation and classification. However, other than for Trichinella pseudospiralis, the absence of distinguishing morphological characters (Lichtenfels et al., 1983) and the overlapping nature of the biological characters (Pozio et al., 1992) within the genus Trichinella make these traits unsuitable for accurate diagnosis.

The multiplex PCR assay designed by Zarlenga et al., (1999) is the method recommended by the Community Reference Laboratory for Trichinella species identification. The PCR allows the comparative analysis of three nucleotide sequences belonging to the internal transcribed spacer 1 and 2 (ITS1 and ITS2) and expansion segment 5 (ESV) of the nuclear ribosomal gene, resulting in the differentiation of all encapsulated and nonencapsulated genotypes of Trichinella.

In India, very inconsistent literature is available on the burden of Trichinellosis in pigs. Hence, considering these facts and importance of disease the current study was carried out to study exact burden of trichinellosis in pigs of Maharashtra, India.

The aim of the present study was to examine occurrence of Trichinella by acid pepsin digestion assay and to standardize multiplex PCR assay to identify two main species of Trichinella i.e. T. spiralis and T. britovi.

\section{Materials and Methods}

The present work was carried out at Department of Veterinary Public Health, Bombay Veterinary College, Mumbai. A total of 161 pig diaphragm samples (males-96 and females -65) were collected aseptically from Deonar abattoir, Mumbai. The majority of the pigs slaughtered in the abattoir were of free ranging pigs. The pigs brought to Deonar abattoir from different areas of Maharashtra viz., Dhule, Ratnagiri, Jalgaon, Yerwada, Pune, Nagpur, Palghar, Bhavanipeth and Nanded. The relative information of pigs i.e. place, sex and age etc. was noted down. The pigs were of medium body condition with an average carcass weight of $35 \mathrm{~kg}(15-55 \mathrm{~kg})$.

Approximately 10-15 g of diaphragm muscle (161), (which is one of the most common predilection sites of Trichinella parasite) was collected from pigs.

The diaphragm muscle samples were collected in polyethylene bags and transported to laboratory in chilled condition in an 
insulated sample collection box containing ice packs. The diaphragm muscle samples were stored at $-18^{0} \mathrm{C}$ till further processing. Prior to process, the samples were thawed in chiller $\left(4-8^{0} \mathrm{C}\right)$. Then the samples were prepared for the detection of Trichinella spp.

All the samples were subjected for identification of Trichinella larvae by Acidpepsin digestion assay as per the protocol of OIE (2012). From each sample, $5 \mathrm{~g}$ muscle was weighed and minced then $250 \mathrm{ml}$ of $0.55 \%$ Acid (Conc.HCl) and $0.5 \mathrm{~g}$ Pepsin (1:10000) was added and transferred into a beaker. Digests were mixed vigorously on a magnetic stir plate at $45^{\circ} \mathrm{C}$ for $30 \mathrm{~min}$. At the end of $30 \mathrm{~min}$, the digest was allowed to settle and the supernatant was decanted. The sediment was poured through a mesh sieve into separatory funnel and allowed to settle for $30 \mathrm{~min}$, then $10 \mathrm{ml}$ sediment fluid was collected in Petri dish and examined using a stereo microscope at a $10 \mathrm{X}$ magnification.

In the present study, larvae of $T$. britovi and T. spiralis were procured from Laboratory of IstitutoSuperiore di Sanita, Department of Infectious, Parasitic and Immuno mediated Diseases, Rome, and used to standardize multiplex PCR assay.

DNA was extracted from larvae as per the procedure described by Guenther et al., (2008) with slight modifications. The microcentrifuge tube containing larvae was centrifuged at $10,000 \mathrm{rpm}$ for $5 \mathrm{~min}$ to allow the larva to settle at the bottom of the tube and excess ethanol was discarded leaving minimum volume. After centrifugation, $2 \mu \mathrm{l}$ of TRIS- $\mathrm{HCl}$ buffer (50mM, pH 7.4-7.6) was added to tube containing Trichinella larva in 5 $\mu \mathrm{l}$ distilled water and sealed with a drop of mineral oil. The tube was heated at $90^{\circ} \mathrm{C}$ for $10 \mathrm{~min}$ in hot water bath and cooled to room temperature. Proteinase K $(20 \mathrm{mg} / \mathrm{ml}) 0.4 \mu \mathrm{l}$ was added to the tube and incubated at $48^{\circ} \mathrm{C}$ for $3 \mathrm{hrs}$. At the end of the incubation, the tube was heated at $90^{\circ} \mathrm{C}$ for $10 \mathrm{~min}$ to inactivate the proteinase $\mathrm{K}$. The proteinase $\mathrm{K}$ treated larva was used for DNA extraction using DNASure ${ }^{\circledR}$ Tissue Mini Kit (Genetix Biotech Asia, New Delhi) as per the manufacturer's instructions. DNA concentrations were determined spectrophotometrically. Final DNA concentration was adjusted to 200ng by using MiliQ water.

The PCR assay was standardized to amplify the ESV and ITS1 region of nuclear ribosomal gene of the Trichinella parasite as per the method described by Zarlenga et al., (1999) with slight modifications. Subsequently a total of 100 randomly selected diaphragm samples (males-60 and females40) of pig which showed absence of Trichinella larvae by HCl-pepsin digestion assay were subjected for DNA extraction by DNASure ${ }^{\circledR}$ Tissue Mini Kit. The isolated DNA from the tissues was used for the multiplex PCR analysis by keeping DNA extracted from standard as a positive control. All the samples showed negative results for Trichinella spp.

The PCR was done by using the primers ESV(Forward- 5'-GTT CCA TGT GAA CAG CAG T-3' and reverse-5'-CGA AAA CAT ACG ACA ACT GC-3') and ITS1 (forward5'-GCT ACA TCC TTT TGA TCT GTT-3' reverse- 5'AGA CAC AAT ATC AAC CAC AGT ACA-3') in order to obtain the best amplification product by optimizing varying the quantity of $\mathrm{MgCl}_{2}$, template DNA concentration, primer concentration, annealing temperature and time. Briefly, the multiplex PCR assay was performed in Master Cycler Gradient Thermocycler (Eppendorf, Germany) having a pre-heated lid. The reaction mixture was performed containing $2.5 \mu 110 \mathrm{x}$ PCR buffer, 1.0 $\mu \mathrm{l}$ dNTP Mix (10mM each), $1.0 \mu 1 \mathrm{Mgcl}_{2}(50 \mathrm{mM})$, 
$0.5 \mu 1$ each of ESV and ITS1 forward and reverse primers, $1.0 \mu 1$ Taq DNA polymerase (2.5 U/ $\mu \mathrm{l}), 4 \mu \mathrm{l}$ Template DNA, $1.5 \mu \mathrm{l}$ Glycerol and Nuclease free water to make the total volume $25 \mu \mathrm{l}$. PCR assay was performed with an initial denaturation step at $94^{\circ} \mathrm{C}$ for 5 min followed by 35 cycles each of denaturation at $94^{0} \mathrm{C}$ for $1.5 \mathrm{~min}$, annealing at $54^{0} \mathrm{C}$ for $1 \mathrm{~min}$ and extension at $72^{\circ} \mathrm{C}$ for 1 min followed by final extension at $72^{0} \mathrm{C}$ for 5 min. PCR products were kept at $-18^{\circ} \mathrm{C}$ until further analysis by agarose gel electrophoresis. In each PCR assay, a negative control was also kept. PCR products were separated by $1.5 \%$ agarose gel electrophoresis at $95 \mathrm{~mA}$ and stained with ethidium bromide.

\section{Results and Discussion}

In the present study a total of 161 pig diaphragm samples were analyzed using Acid-pepsin digestion assay but none of the sample was found to be positive for Trichinella spp.

The results observed in the present study shows nil occurrences for Trichinellosis in study areas. The previous studies conducted in India suggest nil prevalence of Trichinellosis in pigs (Ramamurthi and Ranganathan, 1968; Pethe and Narsapur, 1992; Gaurat and Gatne, 2005). Studies conducted in Maharashtra reported low prevalence ranges from $0.27 \%$ to $0.86 \%$ using acid pepsin digestion assay (Jundale, 2015 and Panchal, 2016).

Many studies suggest serological evidence even after negative results by Acid-pepsin digestion assay (Karn, 2007; Konwar et al., 2017). Similarly the directive 77/96/EEC on Pepsin digestion test has a confirmed detection limit of 1-3 larvae/g which may be the reason for non positivity in current study in pigs with low level of infection.

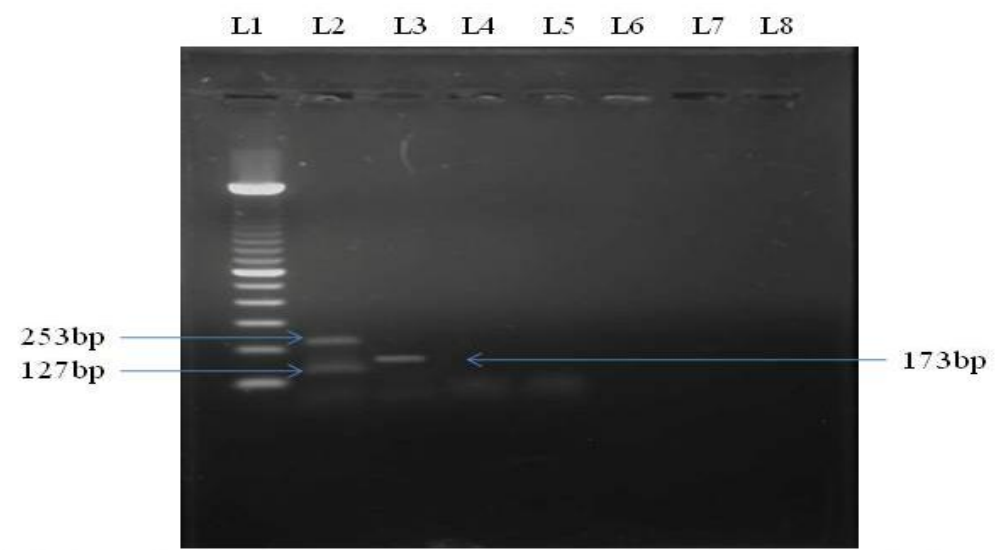

Fig No.1: Electrophoresis pattern of amplified product of samples by multiplex PCR using ESV and ITS1 primers.

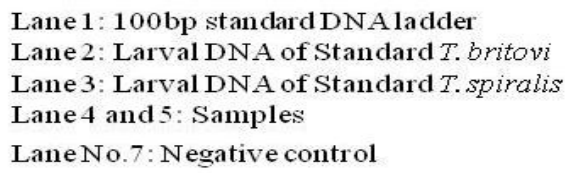

Results from agarose gel electrophoresis of multiplex PCR products using DNA extracted from diaphragm tissue keeping reference strains of T.britovi and T.spiralis as a positive control are shown in Figure 1. By multiplex PCR assay, none of the sample was found to 
be positive for Trichinella. Standardized PCR results indicate indicate unique and simple banding patterns for each of the genotypes. Amplified products of $T$. britovi showed genotype fragment size of 127 and 253 bp for ESV and ITS1 primers, respectively. Whereas, T. spiralis showed only one genotype fragment size of $173 \mathrm{bp}$ for ESV. This indicates that standardized cycling conditions in this multiplex PCR can be useful for differentiation of $T$. britovi and $T$. spiralis larvae in Indian condition. The standardized multiplex PCR assay was to be used for identifying all genotypes and species of Trichinella larvae, if the larvae would have been isolated from tissues by Acid-pepsin digestion assay.

Various workers used Multiplex PCR assay for differentiating species of Trichinella in different geographical conditions and for different strains (Kapel et al., 2001; Pozio et al., 2004; Hurnıkova et al., 2005; De Bruyne et al., 2005 Merialdi et al., 2011 andKirjusina et al., 2015). Among the EVS and ITS1 primers, ESV is the only nucleotide sequence present in all species of Trichinella but it is highly variable in size and nucleotide sequence for each Trichinella spp. However ITS1 nucleotide sequence is present only in $T$. britovi. Thus this method can be useful to differentiate between T.spiralis and T.britovi which are reported in India. Along with this, standardized PCR can be used to differentiate all species of Trichinella due to its unique banding pattern for ESV primers in each species. Thus this method is simple, specific and cost effective for diagnosis of Trichinella spp.

The current study demonstrated non detectable occurrence of Trichinellosis in domestic pigs by Acid -pepsin digestion assay and multiplex PCR assay but it is necessary to study epidemiological situation of parasitic diseases. Regular monitoring and surveillance by acid pepsin digestion assay and multiplex PCR in synanthropic animals like rodents, other domestic animals and wildlife is essential to have a complete scientific data on prevalence of Trichinellosis in India.

\section{Acknowledgment}

We are immensely thankful to Mr. Edoardo Pozio, Head of Laboratory, Istituto Superiore di Sanita, Department of Infectious, Parasitic and Immuno mediated Diseases, Rome, Italy for providing reference larvae of Trichinella for standardization of PCR. We are thankful to the project entitled "Outreach Programme on Zoonotic Diseases" sponsored by ICAR in the Department of Veterinary Public Health, BVC, Mumbai for providing financial help in terms of chemicals and reagents for research work.

Conflict of interest: The authors declare that they have no any conflict of interest.

\section{References}

Campbell WC. 1988. Trichinosis revisitedanother look at modes of transmission. Parasitol Today 4:83-86

Chethankumar, H. B., 2011. Studies on incidence and molecular characterization of Trichinella spp. in pigs slaughtered at Deonar abattoir. M.V.Sc. thesis submitted to Maharashtra Animal and Fishery Sciences University, Nagpur.

De Bruyne, A., H. Yera, F. Le Guerhier, P. Boireau and J. DupouyCamet,.2005.Simple species identification of Trichinella isolates by amplification and sequencing of the 5S ribosomal DNA intergenic spacer region. Vet. Parasitol. 132: 57-61.

Dupouy-Camet, J., 2000. Trichinellosis: a worldwide zoonosis. Vet. Parasitol. 
93, 191-200.

Gajadhar, A. A., W. B. Scandrett and L. B. Forbes, 2006. Overview of food- and water-borne zoonotic parasites at the farm level. Rev. Sci. Tech. Off. Int. Epiz. 25(2): 595-606.

Gaurat, R. P. and M. L. Gatne, 2005. Prevalence of helminth parasites in domestic pigs (Sus scrofadomestica) in Mumbai: an abattoir survey. J. Bombay Vet. Coll. 13: 100-102.

Gottstein, B., E. Pozio and K. Nockler, 2009. Epidemiology, diagnosis, treatment, and control of trichinellosis. Clin. Microbiol. Rev. 22(1): 127-145.

Guenther, S., K. Nockler, M. V. NickischRosenegk, M. Landgraf, C. Ewersa, H. Lothar Wieler and P. Schierack, 2008. Detection of Trichinella spiralis, Trichinella britovi and Trichinella pseudospiralis in muscle tissue with real-time PCR. J. Microbiol. Methods. 75(2): 287-292.

Hurnı'kova Z., V. Snabel, E. Pozio, K. Reiterova, G. Hrckova, D. Halasova, P. Dubinsky, 2005.First record of Trichinellapseudospiralis in the Slovak Republic found in domestic focus. Vet. Parasitol. 128: 91-98

Jundale, D. V, 2015. Prevalence of trichinella spp. In pigs slaughtered in Maharashtra state. (M. V. Sc thesis submitted to MAFSU, Nagpur, India)

Kalapesi, R. M. and S. R. Rao, 1954. Trichinella spiralis infection in a cat that died in the zoological gardens, Bombay. Indian Medical Gazette. 89: 578-585.

Kapel, C. M. O., L. Oivanen, G. La Rosa, T. Mikkonen and E. Pozio, 2001.Evaluation of two PCR-based techniques for molecular epidemiology in Finland, a highendemic area with four sympatric Trichinella species. Parasite J. 8: S39S43.
Karn S.K.,2007. A cross-sectional study of Trichinella spp. in pigs in the central development region of Nepal using pepsin digestion and ELISA serology. Thesis submitted to Chiangmai university and Freie university Berlin.

Kirjusina, M., G. Deksne, G. Marucci, E. Bakasejevs, I. Jahundovica, A. Daukste, A. Zdankovska, Z. Berziņa, Z. Esite, A. Bella, F. Galati, A. Krumina and E. Pozio, 2015. A 38year study on Trichinella spp. in wild boar (Sus scrofa) of Latvia shows a stable incidence with an increased parasite biomass in the last decade Parasites \& Vectors 8: 137.

Konwar, P., B. B. Singh, J. P. S. Gill, 2017. Epidemiological studies on trichinellosis in pigs (Sus scofa) in India. J Parasit Dis 41(2):487-490.

Lichtenfels JR, Murrell KD, Pilitt PA, 1983. Comparison of three subspecies of Trichinella spiralis by scanning electron microscopy. J Parasitol; 69: 1131- 40.

Merialdi, G., L. Bardasi, M. C. Fontana, B. Spaggiari, G. Maioli, G. Conedera, D. Vio, M. Londero, G. Marucci, A. Ludovisi, E. Pozio, G. Capelli, 2011.First reports of Trichinella pseudospiralis in wild boars (Sus scrofa) of Italy. Vet. Parasitol. 178:370-373

Niphadkar, S. M., 1973. Trichinella spiralis (Owen, 1835) in Bandicoota bengalensis (Gray) in Bombay. Current Sci. 42(4): 135-136.

Panchal, S.G., 2016. Studies on prevalence of trichinellosis in pigs, rodents and humans. (M.V. Sc thesis Submitted to Maharashtra Animal And Fishery Sciences University, Nagpur, India)

Pethe, R. S. and V. S. Narsapur, 1992. Observations of haematology, immune response and treatment of Trichinella spiralis in experimental animals. 
(M.V.Sc. thesis approved by Konkan Krishi Vidyapeeth, Dapoli, Maharashtra, India).

Pozio E, La Rosa G, Rossi P, Murrell KD., 1992. Biological characterization of Trichinella isolates from various host species and geographical regions. J Parasitol;78:647-53.

Pozio E.,D. Christensson, M. Steen, G. Marucci, G. L. Rosa, C. Brojer, T. Morner, H. Uhlhorn, E. Agren, M. Hall, 2004. Trichinella pseudospiralis foci in Sweden. Vet. Parasitol. 125:335-342.

Ramamurthi, R. and M. Ranganathan, 1968.
A survey of incidence of trichinosis in pigs in Madras city. Indian Vet. J. 45(9): 740-742.

Singh, B. B., S. Ghatak, H. S. Banga, J. P. S. Gill and B. Singh, 2013. Veterinary urban hygiene - challenge for India. Rev Sci Tech Off IntEpiz 32(3):645656

Zarlenga, D. S., M. B. Chute, A. Martin and C. M. O. Kapel, 1999. A multiplex PCR for unequivocal differentiation of all encapsulated and non-encapsulated genotypes of Trichinella. Int. J. Parasitol. 29: 1859-1867.

\section{How to cite this article:}

Kale, L.N., R.N. Waghamare, V.M. Vaidya, R.J. Zende, A.M. Paturkar, R.G. Shende, N.B. Aswar and Kshirsagar, D.P. 2018. Studies on Occurrence of Trichinellosis in Pigs and Its Molecular Characterization Using Multiplex PCR in Maharashtra, India. Int.J.Curr.Microbiol.App.Sci. 7(08): 4451-4457. doi: https://doi.org/10.20546/ijcmas.2018.708.470 